\title{
IMPROVING PROBLEM-SOLVING SKILL IN PLANE FIGURE AND SOLID FIGURE ESSAY THROUGH THE ASSURANCE, RELEVANCE, INTEREST, ASSESSMENT, SATISFACTION (ARIAS) LEARNING METHODOLOGY
}

\author{
Desi Yulanda Putri, Retno Winarni, Anesa Surya
}

Universitas Sebelas Maret

yohanadesiyp@gmail.com

Article History

accepted 09/07/2018

approved 01/08/2018

published 17/09/2018

\section{Keywords}

Problem Solving, ARIAS

Learning Model

\begin{abstract}
The students'ability level of solving the problem is still low. Regarding the importance of having the problem-solving skill itself, there should be alternative methods to support the students to solve the problem. The aim of this research is to examine the increased level of problem-solving skill on a plane figure and a solid figure essay by Assurance, Relevance, Interest, Assessment, Satisfaction (ARIAS) learning model for grade $V$ students of SD Negeri Tunggulsari II No. 179 Surakarta academic year 2017/2018. This research conducted in two cycles with the teacher and 29 students from grade $V$ as the subject. The data were collected by interview, observation, test, and document review. Data validaty is tested by content validity, triangulation of source and technique. The results show that the use of ARIAS learning model improving the problemsolving skill on a plane figure and solid figure essay. It can be proven by the increasing percentage of classical completeness on the pre-cycle of $17,24 \%$, increased to $27,59 \%$ in the first cycle and increased to $86,21 \%$ in the second cycle. The conclusion of this research is the ARIAS learning model can improve the problem-solving skill of plane figure and solid figure essay on grade V students of SD Negeri Tunggulsari II No. 179 Surakarta academic year 2017/2018.
\end{abstract}

Social, Humanities, and Education Studies (SHEs): Conference Series https://jurnal.uns.ac.id/shes

p-ISSN 2620-9284 e-ISSN 2620-9292 


\section{PENDAHULUAN}

Pendidikan memegang peranan penting dalam membentuk keterampilan dan kecakapan seseorang untuk memajukan suatu bangsa. Salah satu cara yang dapat dilakukan untuk memajukan suatu bangsa adalah melalui pendidikan di sekolah dasar. Pendidikan sekolah dasar merupakan pondasi utama dalam pendidikan nasional. Pada jenjang sekolah dasar salah satu mata pelajaran yang dipelajari adalah matematika. Levin (2012) menyatakan bahwa identifies 21st century skills as critical thinking, problem solving, communication, collaboration, and creativity. Pada abad 21, keterampilan yang harus dikuasai salah satunya adalah keterampilan pemecahan masalah. Pemecahan masalah merupakan proses menerapkan pengetahuan (knowledge) yang telah diperoleh siswa sebelumnya ke dalam situasi yang baru (Susanto, 2013). Dalam ilmu matematika, masalah dibagi menjadi dua yaitu: (1) masalah yang berkaitan dengan soal cerita (textbook word); (2) masalah yang berkaitan dengan proses pembelajaran (process problem), (Shadiq, 2014). Dalam menghadapi sebuah masalah membutuhkan suatu perencanaan yang baik untuk menyelesaikannya. George Polya menjelaskan langkah-langkah penyelesaian masalah, sebagai berikut: (1) memahami masalah, (2) menyusun Perencanaan, (3) melaksanakan Perencanaan pemecahan masalah, (4) memeriksa kembali dan menyimpulkan, (Sukirman, 2016).

Soal cerita matematika merupakan kompetensi dasar yang harus dikuasai oleh siswa. Menurut Winarni dan Harmini (2015) soal cerita adalah soal matematika yang diungkapkan atau dinyatakan dengan kata-kata atau kalimat-kalimat dalam bentuk cerita yang dikaitkan dengan kehidupan sehari-hari. Materi pemecahan masalah yang diajarkan pada siswa kelas $\mathrm{V}$ sesuai dengan silabus Kurikulum Tingkat Satuan Pendidikan (KTSP) pelajaran matematika kelas V semester I memiliki standar kompetensi yaitu memahami sifat-sifat bangun dan hubungan antar bangun dan kompetensi dasar yaitu menyelesaikan masalah yang berkaitan dengan bangun datar dan bangun ruang sederhana. Bangun datar adalah bangun geometri yang seluruh bagiannya terletak pada satu bidang. Jenis-jenis dari bangun ruang, antara-lain: persegi, persegi panjang, trapezium, dan layang-layang. Bangun ruang adalah bangun geometri yang memiliki tiga dimensi yaitu; panjang, lebar, dan tinggi. Adapun jenisjenis dari bangun ruang, antara lain; kubus, dan balok; (Rosimanidar, 2014).

Pemecahan masalah soal cerita bangun datar dan ruang merupakan salah satu permasalahan yang sering ditemui pada anak sekolah dasar dalam belajar matematika. Umumnya mereka kesulitan untuk memahami maksud dari soal cerita tersebut, sehingga mereka banyak yang melakukan kesalahan dalam mengerjakan soal yang berhubungan dengan pemecahan masalah soal cerita bangun datar dan ruang. Fakta tentang kesulitan dalam kemampuan memecahkan masalah soal cerita bangun datar dan ruang, ditemui pada hasil pengamatan dan wawancara dengan guru kelas dan siswa Kelas V SD Negeri Tunggulsari II No. 179 Surakarta pada tanggal 2 Februari 2018. Diperoleh data bahwa kemampuan siswa dalam pemecahan masalah soal cerita bangun datar dan ruang masih rendah. Hal ini disebabkan oleh siswa yang kurang aktif dalam proses pembelajaran. Siswa yang kurang aktif dalam pembelajaran dapat dilihat dari kurangnya partisipasi dalam bertanya tentang materi yang masih belum dapat dimengerti. Rendahnya kemampuan siswa dalam pemecahan masalah juga disebabkan oleh model pembelajaran yang diberikan kepada siswa kurang menarik. Guru hanya memberikan penjelasan tentang materi tanpa melihat minat siswa dalam belajar. Siswa kurang bersungguh-sungguh dalam memperhatikan proses pembelajaran yang diberikan oleh guru, sehingga hal ini mempengaruhi kemampuan siswa dalam memecahkan masalah.

Fakta tersebut diperkuat dengan hasil uji pratindakan siswa kelas V SD Negeri Tunggulsari II No. 179 Surakarta yang dilakukan tanggal 2 Februari 2018. Dari hasil uji pratindakan tersebut diketahui bahwa kemampuan siswa dalam menyelesaikan 
masalah berkaitan dengan soal cerita bangun datar dan ruang masih tergolong rendah. Dalam mata pelajaran matematika khususnya materi pemecahan masalah bangun datar dan ruang tergolong rendah karena dari Kriteria Ketuntasan Minimal (KKM) sebesar 70, hanya sedikit siswa yang dapat mencapainya. Berdasarkan daftar nilai pratindakan yang terlampir, menunjukan bahwa dari 29 siswa hanya 5 siswa $(17,24 \%)$ yang berhasil mencapai nilai KKM $(\geq 70)$ dan 24 siswa lainnya $(82,76 \%)$ belum tuntas. Adapun nilai rata-rata tiap aspek kemampuan pemecahan masalah pratindakan adalah aspek memahami masalah sebesar 5,2 dari skor maksimal 20, aspek merencanakan penyelesaian sebesar 15,6 dari skor maksimal 20, aspek menyelesaikan rencana penyelesaian sebesar 29,6 dari skor maksimal 40, dan aspek memeriksa kembali sebesar 9,4 dari skor maksimal 20. Hasil nilai rata-rata uji pratindakan pemecahan masalah soal cerita bangun datar dan ruang ini adalah 59,79. Hasil tersebut menunjukan bahwa komponen pemecahan masalah yang kurang dikuasai oleh siswa adalah memahami masalah, dan memeriksa kembali. Komponen yang sulit dipahami siswa tersebut, menyebabkan hasil pratindakan tidak dapat mencapai nilai yang memuaskan. Siswa terbiasa menjawab soal secara langsung dengan menghitungnya tanpa memperhatikan langkah-langkah penyelesaian soal cerita, sehingga mereka mengalami kesulitan dalam mengerjakannya.

Berdasarkan hasil pratindakan tersebut membuktikan bahwa tingkat kemampuan siswa dalam menyelesaikan masalah masih rendah. Kondisi seperti ini apabila masih dibiarkan terus-menerus dapat menyebabkan rendahnya pengetahuan siswa dalam kemampuan memecahkan masalah di kehidupan sehari-hari yang berkaitan dengan hitung menghitung. Pengaruh lain dari rendahnya pengetahuan pemecaham masalah adalah siswa tidak memiliki kemampuan-kemampuan yang bemanfaaat untuk mengatasi masalah-masalah yang akan dihadapi siswa di masa depan.

Mengingat pentingnya kemampuan pemecahan masalah bagi siswa, maka dicarilah alternatif untuk dapat menyelesaikan permasalahan tersebut. Salah satunya dengan menggunakan pendekatan model pembelajaran yang baik untuk menunjang kemampuan siswa dalam memecahkan masalah. Menurut pendapat Rahman \& Amri (2014) model yang tepat digunakan adalah model pembelajaran ARIAS (Assurance, Relevance, Interest, Assesment, Satisfaction). Model ini adalah sebuah model pembelajaran yang dapat mempengaruhi motivasi berprestasi dan hasil belajar siswa. Hakikat model pembelajaran ARIAS menyatakan bahwa model pembelajaran ARIAS adalah sebuah model pembelajaran yang terdiri dari lima kompenen utama yaitu assurance (percaya diri), relevance (relevansi), interest (minat/perhatian), assestment (penilaian/evaluasi), dan satisfaction (penguatan).

Kelebihan dari model pembelajaran ARIAS yaitu memperoleh dan menguasai materi baru, menumbuhkan rasa percaya diri dalam mengemukakan pendapat yang dimiliki, dan menumbuhkan minat dan perhatian siswa terhadap pembelajaran matematika serta motivasi siswa untuk belajar semakin besar sehingga berpengaruh terhadap hasil belajar siswa (Handayani. Dkk, 2013). Model pembelajaran ARIAS juga dapat dipadukan dengan model pembelajaran lain, sehingga kegiatan proses belajar mengajar menjadi lebih menarik. Dengan demikian, penerapan model pembelajaran ARIAS ini diharapkan dapat menumbuhkan motivasi belajar dan meningkatkan hasil belajar siswa, khususnya dalam matei pemecahan masalah bangun datar dan ruang.

Berdasarkan latar belakang masalah diatas, maka rumusan masalah yang dapat diajukan dalam penelitian ini adalah "Apakah penerapan model pembelajaran Assurance, Relevance, Interest, Assesment, Satisfaction (ARIAS) dapat meningkatkan kemampuan pemecahan masalah soal cerita bangun datar dan ruang pada siswa kelas V SD Negeri Tunggulsari II No. 179 Surakarta tahun ajaran 2017/2018?". Tujuan dari penelitian ini sesuai dengan rumusan masalah, yaitu untuk meningkatkan kemampuan pemecahan masalah soal cerita bangun datar dan ruang melalui model 
pembelajaran Assurance, Relevance, Interest, Assesment, Satisfaction (ARIAS) pada siswa kelas V SD Negeri Tunggulsari II No. 179 Surakarta tahun ajaran 2017/2018.

\section{METODE}

Penelitian Tindakan Kelas (PTK) ini dilaksanakan di SD Negeri Tunggulsari II No. 179 Surakarta. Penelitian ini dilaksanakan dalam jangka waktu 6 bulan yaitu mulai Januari 2017 sampai dengan Juni 2018. Subjek penelitian adalah peneliti sendiri selaku pengajar saat melakukan tindakan, guru kelas $\mathrm{V}$ sebagai observator, dan siswa kelas V SD Negeri Tunggulsari II No. 179 Surakarta tahun ajaran 2017/2018 yang berjumlah 29 siswa, yang terdiri dari 21 putri dan 8 putra. Terdapat empat teknik pengumpulan data pada penelitian ini yaitu: observasi, wawancara, tes, dan dokumentasi. Pada kegiatan observasi hal-hal yang diamati berkaitan dengan komponen-komponen pembelajaran ARIAS, misalnya; Assurance (percaya diri), Relevance (relevansi/ kehidupan sehari-hari), Interest (minat), Assessment (evaluasi), Satification (penguatan). Wawancara dengan guru kelas V SD Negeri Tunggulsari II No. 179 Surakarta dilakukan sebelum dan sesudah peneliti mengadakan tindakan. Wawancara yang dilakukan pada penelitian ini adalah wawancara terstruktur. Dalam penelitian ini, tes dilaksanakan sebelum tindakan atau tes awal (pretest) dan tes setelah melakukan tindakan dengan menerapkan model pembelajaran Assurance, Relevance, Interest, Assessment, Satification (ARIAS) yang diperoleh dari siklus I dan siklus II yang berupa 5 butir soal tentang kemampuan pemecahan masalah soal cerita bangun datar dan ruang. Dokumentasi yang diperoleh meliputi: silabus matematika kelas V, Rencana Pelaksanaan Pembelajaran (RPP) Kelas V, hasil observasi selama proses pembelajaran, evalusi siswa kelas $\mathrm{V}$, dan foto kegiatan pembelajaran kelas $\mathrm{V}$ SD Negeri Tunggulsari II No. 179 Surakarta sebelum dan sesudah menerapkan model pembelajaran Assurance, Relevance, Interest, Assessment, Satification (ARIAS).

Uji validitas yang digunakan dalam penelitian ini adalah uji validitas isi terkait validasi instrumen, peneliti telah berkonsultasi dengan dosen pembimbing dan meminta pertimbangan ahli (expert jugdement), selain itu menggunakan triangulasi sumber, dan triangulasi teknik. Triangulasi sumber misalnya sumber dari teman, guru, dan orang tua. Sedangkan, triangulasi teknik misalnya dengan wawancara lalu dicek dengan observasi, test, selanjutnya dokumentasi. Aktivitas dalam teknik analisis data menggunakan model analisis interaktif yang terdiri dari 3 komponen yaitu reduksi data, penyajian data, dan penarikan kesimpulan. Pengumpulan data dilakukan sebelum dan setelah melaksanakan tindakan siklus I dan II. Pengumpulan data ini dilakukan melalui wawancara, observasi, tes, dan dokumentasi. Data yang direduksi adalah (1) data kondisi siswa kelas V SD Negeri Tunggulsari II No. 179 Surakarta, (2) data hasil observasi dan wawancara guru dan siswa kelas V SD Negeri Tunggulsari II No. 179 Surakarta tahun ajaran 2017/ 2018 sebelum dan sesudah menggunakan model Assurance, Relevance, Interest, Assessment, Satification (ARIAS), (3) data nilai hasil kemampuan pemecahan masalah soal cerita bangun datar dan ruang siklus I dan siklus II, (4) Dokumentasi foto dan video yang kurang mendukung dilakukan reduksi. Data yang disajikan pada penelitian ini antara lain; data sebelum tindakan, siklus I, dan siklus II. Kesimpulan haruslah sejalan dengan rumusan masalah dan tujuan penelitian. Kesimpulan yang diperoleh tersebut yaitu peningkatan pemecahan masalah siswa kelas $\mathrm{V}$ pada pembelajaran matematika. Prosedur penelitian tindakan kelas difokuskan pada empat bagian pokok. Setiap siklus terdiri dari empat tahap yaitu: perencanaan, pelaksanaan tindakan, observasi, dan refleksi tindakan. 
HASIL DAN PEMBAHASAN

Kemampuan pemecahan masalah soal cerita bangun datar dan ruang mengalami peningkatan setiap pertemuan. Pada kondisi awal kemampuan pemecahan masalah soal cerita bangun datar dan ruang masih rendah. Berikut ini, disajikan tabel 1 hasil pratindakan kemampuan pemecahan masalah soal cerita bangun datar dan ruang sebelum melakukan tindakan.

Tabel 1. Distribusi Frekuensi Nilai Kemampuan Pemecahan Masalah Pratindakan

\begin{tabular}{|c|c|c|c|c|c|c|}
\hline \multirow{2}{*}{ No } & \multirow{2}{*}{ Interval } & \multirow{2}{*}{$\begin{array}{l}\text { Median } \\
\text { (xi) }\end{array}$} & \multirow{2}{*}{$\begin{array}{l}\text { Frekuensi } \\
\text { (fi) }\end{array}$} & \multirow{2}{*}{ fi.xi } & \multicolumn{2}{|c|}{ Persentase } \\
\hline & & & & & Relatif & Kumulatif \\
\hline 1 & $38-43$ & 40,5 & 1 & 40,5 & $3,45 \%$ & $3,45 \%$ \\
\hline 2 & $44-49$ & 46,5 & 0 & 0 & $0 \%$ & $3,45 \%$ \\
\hline 3 & $50-55$ & 52,5 & 4 & 210 & $13,79 \%$ & $17,24 \%$ \\
\hline 4 & $56-61$ & 58,5 & 17 & 994,5 & $58,62 \%$ & $75,86 \%$ \\
\hline 5 & $62-67$ & 64,5 & 1 & 64,5 & $3,45 \%$ & $79,31 \%$ \\
\hline 6 & 68-73 & 70,5 & 6 & 423 & $20,69 \%$ & $100 \%$ \\
\hline \multicolumn{2}{|c|}{ Jumlah } & & 29 & 1732,5 & $100 \%$ & \\
\hline \multicolumn{4}{|c|}{ Nilai rata-rata } & \multicolumn{3}{|c|}{59,74} \\
\hline \multicolumn{4}{|c|}{ Ketuntasan Klasikal (Tuntas) } & \multicolumn{3}{|c|}{$17,24 \%$} \\
\hline \multicolumn{4}{|c|}{ Tidak Tuntas } & \multicolumn{3}{|c|}{$82,76 \%$} \\
\hline \multicolumn{4}{|c|}{ Nilai Tertinggi } & \multicolumn{3}{|c|}{71} \\
\hline \multicolumn{4}{|c|}{ Nilai Terendah } & \multicolumn{3}{|c|}{38} \\
\hline
\end{tabular}

Berdasarkan tabel 1 menunjukan bahwa siswa paling banyak memperoleh nilai antara interval 56-61 dengan jumlah siswa yaitu 17 siswa atau sebanyak $58,62 \%$. Dengan demikian, dapat diketahui bahwa lebih dari 50\% siswa masih belum mencapai nilai KKM. Rata-rata kemampuan pemecahan masalah siswa sebelum menggunakan model pembelajaran ARIAS adalah 59,74. Hasil rata-rata ini menunjukan bahwa masih banyak siswa yang belum dapat mencapai nilai KKM atau masih banyak siswa yang memperoleh nilai $<70$ (KKM). Siswa yang mendapatkan nilai di bawah KKM $(\leq 70)$ adalah 5 siswa atau sebesar 17,24\%. Siswa yang mendapatkan nilai di atas KKM ( $\leq$ 70) adalah 21 siswa atau sebesar $82,76 \%$. Nilai tertinggi mencapai 71 dan nilai terendah 38. Hal tersebut, menunjukkan bahwa kemampuan pemecahan masalah soal cerita bangun datar dan ruang siswa kelas V SD Negeri Tunggulsari II No. 179 Surakarta dalam kategori rendah. Faktor yang paling mempengaruhi adalah kurangnya variasi dalam pembelajaran, siswa cenderung pasif atau tidak bertanya dalam pembelajaran tentang materi yang masih belum dapat dimengerti dan kurangnya pemahaman tentang langkah-langkah pemecahan masalah.

Solusi yang tepat untuk mengatasi permasalahan tersebut adalah memberikan suatu variasi pembelajaran. Salah satunya yaitu penggunaan model pembelajaran yang interaktif. Model pembelajaran interaktif ini dapat berupa model pembelajaran Assurance, Relevance, Interest, Assesment, Satisfaction (ARIAS). Model pembelajaran ARIAS dapat meningkatkan hasil belajar dan motivasi siswa dalam pembelajaran. Berdasarkan data tersebut, dilaksanakan tindakan kelas untuk meningkatkan kemampuan pemecahan masalah soal cerita bangun datar dan ruang selama 2 siklus. Perolehan nilai kemampuan pemecahan masalah setelah dilakukan tindakan kelas mengalami peningkatan. Hal tersebut, dapat dilihat mulai dari siklus I pertemuan pertama. Hasil nilai keseluruhan pada siklus I dapat dilihat pada tabel 2. 
Tabel 2. Distribusi Frekuensi Nilai Kemampuan Pemecahan Masalah Soal Cerita Bangun Datar dan Ruang Siklus I

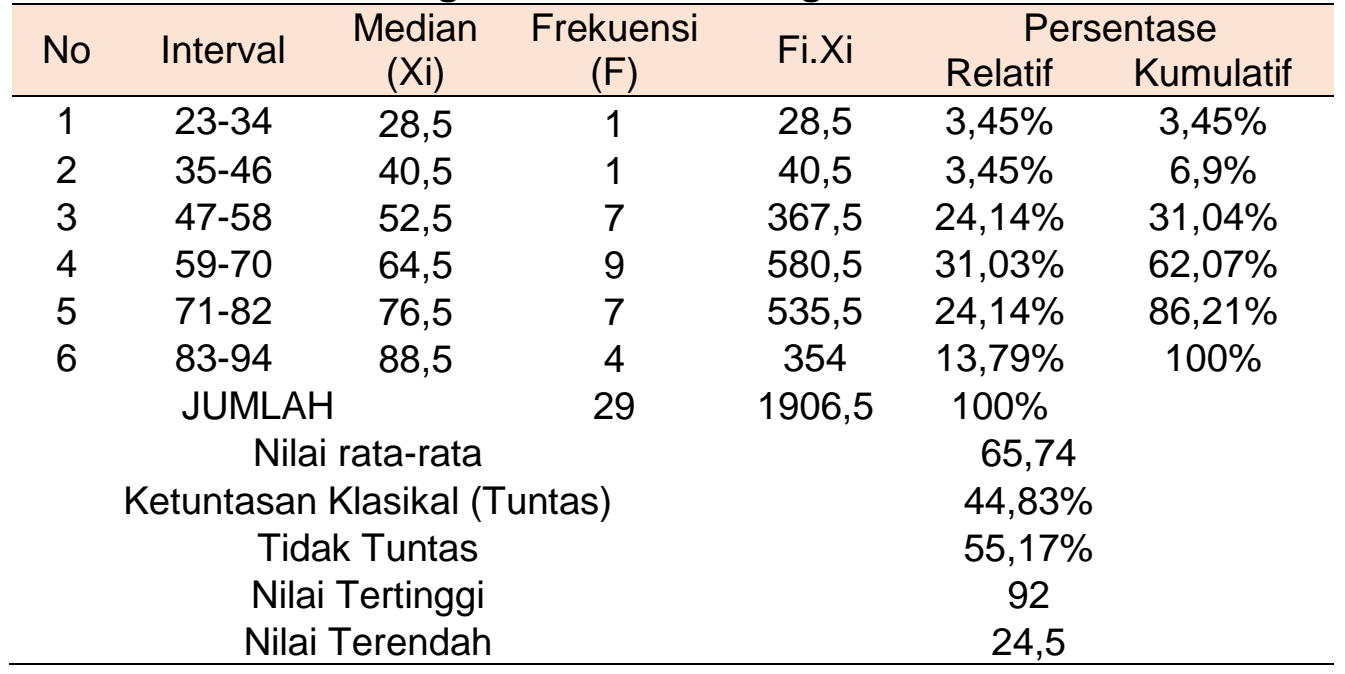

Berdasarkan tabel 2 dapat dilihat bahwa ketuntasan siswa pada siklus I adalah 13 siswa atau 44,83\% tuntas dan 16 siswa atau 55,17\% tidak tuntas. Siswa yang memiliki intervail nilai 23 - 34 sebanyak 1 siswa atau $3,45 \%$. Siswa yang memiliki interval nilai 35 - 46 sebanyak 1 siswa atau 3,45\%. Siswa yang memiliki interval nilai 47 - 58 sebanyak 7 siswa atau $24,14 \%$. Siswa yang memiliki interval nilai $59-70$ sebanyak 9 siswa atau $31,03 \%$. Siswa yang memiliki interval nilai $71-82$ sebanyak 7 siswa atau $24,14 \%$. Siswa yang memiliki interval nilai $83-94$ sebanyak 4 siswa atau $13,79 \%$. Rata-rata kemampuan pemecahan masalah siswa siklus I setelah menggunakan model pembelajaran ARIAS adalah 65,74. Hasil tersebut menunjukan bahwa masih banyak siswa yang belum dapat mencapai nilai KKM atau masih banyak siswa yang memperoleh nilai dibawah $\leq 70(\mathrm{KKM})$. Nilai tertinggi pada siklus I adalah 92 dan nilai terendah adalah 24,5.

Berdasarkan hasil evaluasi siklus I dapat dilihat bahwa terjadi peningkatan kemampuan pemecahan masalah soal cerita bangun datar dan ruang dibandingkan dengan kondisi awal. Namun, siswa masih mengalami kesulitan pada aspek memeriksa kembali dan menyimpulkan. Siswa cenderung bingung dalam membuat simpulan. Oleh karena itu, perlu ditekankan kembali cara-cara dalam menyimpulkan suatu permasalahan yang terdapat dalam soal cerita tersebut. Selain itu, aktivitas siswa siklus I sudah menujukan adanya peningkatan yang dapat dilihat dari adanya beberapa siswa yang sudah mulai bertanya tentang kesulitan pemecahan masalah soal cerita bangun datar dan ruang yang mereka temukan. Namun, masih ada beberapa siswa yang kurang aktif atau pasif selama mengikuti pembelajaran yang dapat dilihat dari adanya beberapa siswa yang diam dan tidak bertanya tentang materi pemecahan masalah soal cerita bangun datar dan ruang. Upaya yang dapat dilakukan untuk mengatasi permasalahan tersebut adalah penggunaan media pembelajaran yang lebih menarik dan memberikan motivasi lebih agar siswa semangat dalam mengikuti pembelajaran.

Perolehan nilai kemampuan pemecahan masalah setelah dilakukan tindakan kelas selanjutnya mengalami peningkatan dari siklus I. Berikut ini disajikan hasil nilai keseluruhan pada siklus II dapat dilihat pada tabel 3. 
Tabel 4. Distribusi Frekuensi Nilai Kemampuan Pemecahan Masalah Soal Cerita Bangun Datar dan Ruang Siklus II

\begin{tabular}{|c|c|c|c|c|c|c|}
\hline \multirow{2}{*}{ No } & \multirow{2}{*}{ Interval } & \multirow{2}{*}{$\begin{array}{c}\text { Median } \\
(\mathrm{Xi})\end{array}$} & \multirow{2}{*}{$\begin{array}{c}\text { Frekuensi } \\
(\mathrm{F})\end{array}$} & \multirow{2}{*}{ Fi.Xi } & \multicolumn{2}{|c|}{ Persentase } \\
\hline & & & & & Relatif & Kumulatif \\
\hline 1 & $51-59$ & 55 & 1 & 55 & $3,45 \%$ & $3,45 \%$ \\
\hline 2 & $60-68$ & 64 & 3 & 192 & $10,34 \%$ & $13,79 \%$ \\
\hline 3 & $69-77$ & 73 & 5 & 365 & $17,24 \%$ & $31,03 \%$ \\
\hline 4 & $78-86$ & 82 & 10 & 820 & $34,49 \%$ & $65,52 \%$ \\
\hline 5 & $87-95$ & 91 & 5 & 455 & $17,24 \%$ & $82,76 \%$ \\
\hline \multirow[t]{7}{*}{6} & $96-104$ & 100 & 5 & 500 & $17,24 \%$ & $100 \%$ \\
\hline & JUMLAH & & 29 & 2387 & $100 \%$ & \\
\hline & \multicolumn{3}{|c|}{ Nilai rata-rata } & & \multicolumn{2}{|l|}{82,31} \\
\hline & \multicolumn{3}{|c|}{ Ketuntasan Klasikal (Tuntas) } & & \multicolumn{2}{|l|}{$86,21 \%$} \\
\hline & \multicolumn{3}{|c|}{ Tidak Tuntas } & & \multicolumn{2}{|l|}{$13,79 \%$} \\
\hline & \multicolumn{3}{|c|}{ Nilai Tertinggi } & & \multicolumn{2}{|l|}{100} \\
\hline & \multicolumn{3}{|c|}{ Nilai Terendah } & & \multicolumn{2}{|l|}{58} \\
\hline
\end{tabular}

Berdasarkan tabel 4 dapat dilihat bahwa ketuntasan siswa pada siklus II adalah 25 siswa ata $86,21 \%$ tuntas dan 4 siswa atau $13,79 \%$ tidak tuntas. Siswa yang memiliki intervail nilai $51-59$ sebanyak 1 siswa atau $3,45 \%$. Siswa yang memiliki interval nilai 60-68 sebanyak 3 siswa atau 10,34\%. Siswa yang memiliki interval nilai 69-77 sebanyak 5 siswa atau 17,24\%. Siswa yang memiliki interval nilai $78-86$ sebanyak 10 siswa atau $34,49 \%$. Siswa yang memiliki interval nilai $87-95$ sebanyak 5 siswa atau $17,24 \%$. Siswa yang memiliki interval nilai $96-104$ sebanyak 5 siswa atau 17,24\%. Dari hasil tersebut menunjukan bahwa siswa sudah dapat memiliki kemampuan dalam pemecahan masalah. Rata-rata kemampuan pemecahan masalah siswa siklus II dengan menggunakan model pembelajaran ARIAS adalah 82,31. Hasil tersebut menunjukan bahwa banyak siswa yang telah mencapai nilai KKM atau banyak siswa yang memperoleh nilai diatas $\leq 70$ (KKM). Nilai tertinggi pada siklus II adalah 100 dan nilai terendah adalah 58 .

Berdasarkan hasil evaluasi siklus II dapat diketahui bahwa kemampuan pemecahan masalah soal cerita bangun datar dan ruang mengalami peningkatan setiap pertemuan. Pada nilai tertinggi peningkatan mulai dari pratindakan sebesar 71 , siklus I sebesar 92, siklus II sebesar 100. Nilai terendah peningkatan mulai dari pratindakan 38 , siklus I sebesar 24,5, siklus II sebesar 58. Rata-rata peningkatan mulai dari pratindakan 59,74, siklus I sebesar 65,74, siklus II sebesar 82,31. Ketuntasan peningkatan mulai dari pratindakan sebesar $17,24 \%$, siklus I sebesar $44,83 \%$, siklus II sebesar $86,21 \%$. Hasil tersebut menunjukan bahwa setiap pertemuan kemampuan pemecahan masalah soal cerita bangun datar dan ruang meningkat. Selain itu, aktivitas siswa siklus II mengalami peningkatan dibandingkan dengan siklus I. Keaktifan siswa sangat baik, ditandai dengan terjadinya komunikasi dua arah, siswa mau bertanya atau berpendapat dengan kesadaran sendiri dan penuh percaya diri. Siswa dapat bekerjasama dengan teman sekelompok dengan sangat baik, ditandai dengan aktif berpartisipasi dalam mengerjakan tugas kelompok, ikut menyumbangkan ide untuk kelompok, dan menghargai pendapat teman selama diskusi. Hasil tersebut menunjukan bahwa terjadi peningkatan aktivitas siswa siklus I pertemuan pertama dibandingkan dengan Siklus II pertemuan kedua.

Setelah dilakukan penelitian sesuai dengan yang telah dipaparkan diatas, maka dapat disimpulkan bahwa model pembelajaran Assurance, Relevance, Interest, Assesment, Satisfaction (ARIAS) dapat meningkatkan kemampuan pemecahan masalah soal cerita bangun datar dan ruang kelas V SD Negeri Tunggulsari II No.179 
Surakarta. Ketuntasan Kriteria Minimal yaitu $\geq 70$ atau kategori baik dapat dijadikan patokan untuk melihat peningkatan kemampuan pemecahan masalah. Kemampuan pemecahan masalah soal cerita bangun datar dan ruang mengalami peningkatan setiap pertemuan. Pada nilai tertinggi peningkatan mulai dari pratindakan sebesar 71 , siklus I sebesar 92, siklus II sebesar 100. Nilai terendah peningkatan mulai dari pratindakan 38 , siklus I sebesar 24,5 , siklus II sebesar 58 . Rata-rata peningkatan mulai dari pratindakan 59,74, siklus I sebesar 65,74, siklus II sebesar 82,31. Ketuntasan peningkatan mulai dari pratindakan sebesar $17,24 \%$, siklus I sebesar $44,83 \%$, siklus II sebesar $86,21 \%$. Hasil tersebut menunjukan bahwa setiap pertemuan kemampuan pemecahan masalah soal cerita bangun datar dan ruang meningkat..

Berdasarkan uraian tersebut, dapat diketahui bahwa pada awal kegiatan sebelum menerapkan model pembelajaran Assurance, Relevance, Interest, Assesment, Satisfaction (ARIAS) atau pratindakan kemampuan siswa dalam pemecahan masalah soal cerita masih rendah dan rata-rata siswa mendapat nilai dibawah KKM. Selanjutnya, setelah menerapkan model pembelajaran ARIAS kemampuan siswa dalam pemecahan masalah soal cerita bangun datar dan ruang meningkat. Hasil penelitian tersebut didukung dengan pendapat Rahman \& Amri (2014) yang menyatakan bahwa model pembelajaran ARIAS terdiri dari lima komponen yang saling berkaitan serta dapat mempengaruhi motivasi belajar dan hasil belajar siswa.

Penelitian yang serupa dengan penelitian ini adalah penelitian dari Dita Maulyta (2017). Persamaan dengan penelitian yang dilakukan oleh Dita Maulyta dengan penelitian ini adalah penerapan model pembelajaran Assurance, Relevance, Interest, Assesment, Satisfaction (ARIAS) dalam kemampuan pemecahan masalah soal cerita. Perbedaan penelitian Dita Maulyta dengan penelitian ini terletak pada materi pembelajaran. Dita Maulyta menerapkan model pembelajaran ARIAS untuk materi pemecahan masalah soal cerita pecahan, sedangkan penelitian ini menerapkan model pembelajaran ARIAS untuk materi pemecahan masalah soal cerita bangun datar dan ruang. Berdasarkan hasil penelitian yang telah dilakukan Dita Maulyta dan peneliti saat ini dapat disimpulkan bahwa model pembelajaran ARIAS dapat meningkatkan kemampuan pemecahan masalah soal cerita.

Dalam menerepkan model pembelajaran Assurance, Relevance, Interest, Assesment, Satisfaction (ARIAS) dihadapkan dengan beberapa kendala antara lain: (1) siswa cenderung malas menuliskan langkah-langkah dalam pemecahan masalah; (2) beberapa siswa ada yang belum terlibat aktif dalam pembelajaran; (3) beberapa siswa ada yang belum percaya diri dalam mengemukakan pendapat; (4) guru belum dapat mengkondisikan kelas saat kegiatan diskusi karena banyak anak yang membuat gaduh. Kendala tersebut dapat diperbaiki pada pertemuan selanjutnya dengan memberikan kesempatan kepada siswa untuk dapat berperan aktif dalam setiap pembelajaran, menjelaskan kembali pentingnya penggunaan langkah-langkah pemecahan masalah dalam menjawab soal cerita, dan membimbing anak yang membuat gaduh untuk tidak mengganggu temannya.

\section{SIMPULAN}

Berdasarkan hasil penelitian dan pembahasan yang telah dilaksanakan dapat disimpulkan bahwa penerapan model pembelajaran ARIAS dapat meningkatkan kemampuan pemecahan masalah soal cerita bangun datar dan ruang kelas $\mathrm{V}$ SD Negeri Tunggulsari II No.179 Surakarta. Penelitian tentang penerapan model pembelajaran ARIAS ini dapat dijadikan sebagai referensi atau pedoman dalam melaksanakan kegiatan pembelajaran matematika khususnya kegiatan pembelajaran materi pemecahan masalah soal cerita bangun datar dan ruang. Adanya penelitian ini diharapkan peneliti lain hendaknya lebih memperhatikan kembali masalah yang ada 
dan lebih mengakaji ulang teori-teori tentang model pembelajaran ARIAS dari berbagai sumber sehingga dapat mengatasi kekurangan-kekurangan yang ada dalam penelitan ini.

\section{DAFTAR PUSTAKA}

Dita, M. dkk. (2017). Peningkatan Kemampuan Pemecahan Masalah Soal Cerita Pecahan Melalui Model Pembelajaran Assurance, Relevance, Interest, Assesment, Satisfaction (ARIAS). Jurnal Didaktika Dwija Indria 5, 2.

Handayani, S., dkk. (2013). Pengaruh Model Pembelajara ARIAS Assurance, Relevance, Interest, Assesment, Satisfaction Terhadap Hasil Belajar Matematika di SD. Jurnal Mimbar PGSD 1, 1.

Levin, J. (2012). Teaching Generation TechX with the 4Cs: Using Technology to Integrate 21st Century Skills. Journal of Instructional Research 1, 59 - 64.

Rahman, M. \& Amri, S. (2014). Model Pembelajaran ARIAS Terintegratif. Jakarta: Prestasi Pustakaraya.

Rosimanidar. (2014). Matematika Dasar. Yogyakarta: Kaukaba Dipantara.

Shadiq, F. (2014). Pembelajaran Matematika Cara Meningkatkan Kemampuan Berpikir Siswa. Yogyakarta: Graha IImu.

Sukirman. (2016). Matematika Untuk Guru dan Caln Guru Pendidikan Dasar. Yogyakarta: UNY Press.

Susanto, A. (2013). Teori Belajar dan Pembelajaran di Sekolah Dasar. Jakarta: Kencana.

Winarni, E. \& Harmini, S. (2015). Matematika Untuk PGSD. Bandung: Remaja Rosdakarya. 